\title{
Characterization of a large-scale ephemeral bloom of the green alga Cladophora sericea on the coral reefs of West Maui, Hawai'i
}

\author{
Jennifer E. Smith ${ }^{1,3, *}$, John W. Runcie ${ }^{2,4}$, Celia M. Smith ${ }^{1}$ \\ ${ }^{1}$ University of Hawai'i Manoa, 3190 Maile Way, Honolulu, Hawai'i 96822, USA \\ ${ }^{2}$ Hawai'i Institute of Marine Biology, PO Box 1346, Kane'ohe, Hawai'i 96744, USA \\ ${ }^{3}$ Present address: National Center for Ecological Analysis and Synthesis, University of California Santa Barbara, \\ 735 State St. Suite 300, Santa Barbara, California 93101, USA \\ ${ }^{4}$ Present address: University of Technology, Sydney, Westbourne St., Gore Hill, New South Wales 2065, Australia
}

\begin{abstract}
The filamentous green alga Cladophora sericea G. Hudson (Kutzing) has formed episodic and ephemeral nuisance blooms on West Maui's coral reefs over the past 2 decades. Despite a paucity of evidence, nutrient-rich runoff, groundwater seepage, and upwelling have all been suggested as the cause of these blooms. The goals of this study were to characterize a number of physical and biological variables during a bloom event that occurred during the summer of 2001. We quantified the nutrient environment (water column and sediment porewater), benthic community structure, and herbivore abundance along a depth gradient in an effort to identify factors that may influence bloom dynamics. Further nutrient enrichment and growth experiments were conducted with $C$. sericea in both the field and the laboratory to determine the response of this alga to enhanced nutrient concentrations. Sediment porewater sampled $0.25 \mathrm{~m}$ into the substrate had high concentrations of ammonium, nitrate, and silicate, and low salinity relative to overlying ambient water, suggesting groundwater intrusion was occurring into the sediment interstices. Tissue samples of $C$. sericea showed elevated nitrogen and $\delta^{15} \mathrm{~N}$ at shallow sites, and these values declined with depth. In situ nutrient enrichments and subsequent determinations of relative electron transport rates (rETR) for $C$. sericea using chlorophyll fluorescence revealed that some samples were nutrient limited and maximum rates of rETR generally increased with enrichment. Further, algae located at sites with the highest concentrations of dissolved inorganic nitrogen did not respond to nutrient enrichment. Growth rates of up to $25 \%$ increase in wet weight $\mathrm{d}^{-1}$ were observed for $C$. sericea in the laboratory when enriched with commercial fertilizer. The results of this study suggest that the bloom of $C$. sericea may have been influenced by land-based nutrients via groundwater seepage, but other physical factors are also likely to be involved in the development, persistence and senescence of this dynamic species.
\end{abstract}

KEY WORDS: Algal blooms $\cdot$ Cladophora sericea $\cdot$ Coral reefs $\cdot$ Nutrients $\cdot$ Phase-shifts $\cdot$ Macroalgae Resale or republication not permitted without written consent of the publisher

\section{INTRODUCTION}

The frequency of algal blooms on coral reefs has increased over the last several decades (Smith et al. 1981, Done 1992, Hughes 1994, Bellwood et al. 2004). In many cases these events result in what is known as a phase-shift or alternate stable state where previously abundant coral species are replaced by fleshy macroalgae (Done 1992, McCook 1999). The causes of such changes in benthic reef community structure seem to vary from region to region and even reef to reef and are the subject of debate within the scientific community (Hughes et al. 1999, Lapointe 1999).

Experimental manipulations show that grazing by herbivores (top-down control) strongly influences the abundance, standing stock and productivity of benthic reef algae (Hatcher \& Larkum 1983, Miller et al. 1999, Lirman 2001, McCook 2001, McCook et al. 2001, Smith 
et al. 2001, Thacker et al. 2001, Williams \& Polunin 2001, Belliveau \& Paul 2002, McClanahan et al. 2002, Diaz-Pulido \& McCook 2003, Jompa \& McCook 2003a,b). The role of bottom-up factors (primarily inorganic nutrients) in influencing algal abundance on reefs has been less clear. In some cases, nutrient enrichment has had little to no effect on algal abundance or community structure (Miller et al. 1999, Thacker et al. 2001, Belliveau \& Paul 2002) while in other studies significant effects have been detected (Hatcher \& Larkum 1983, Lapointe 1997, Smith et al. 2001, McClanahan et al. 2002, Diaz-Pulido \& McCook 2003). A consequence of the extreme variability in nutrient concentrations on reefs in space and time is that not all systems will have a common starting point or similar response to enrichment. Further, the methods (specifically the amount and frequency of enrichment and the length of study) that have been used to conduct these experiments were not consistent among studies. These considerations make cross-comparisons difficult. Both top-down and bottom-up factors are likely to be important in structuring benthic reef communities; their relative importance will ultimately depend on past history and other physical and biological factors associated with a particular site (Hughes \& Connell 1999, Porter et al. 1999, Knowlton 2001).

In general, the transition from coral to algal dominance usually occurs gradually but persists, with the resulting algal community represented by a multispecies assemblage or a single robust species. In Kane'ohe Bay, Hawai'i, several decades of overfishing and sedimentation combined with extensive sewage pollution led to the proliferation of the green alga Dictyosphaeria cavernosa in the 1970s (Banner 1974, Smith et al. 1981, Maragos et al. 1985, Hunter \& Evans 1995). However, despite the removal of the nutrient source in the 1980s, the bay still supports dense macroalgal stands composed not only of $D$. cavernosa but of 3 non-indigenous red algae as well (Larned 1998, Stimson et al. 2001, Smith et al. 2002). At Discovery Bay, Jamaica, a combination of decades of overfishing, hurricane disturbance, coastal development and finally the 1982-1983 massive die-off of the sea urchin Diadema antillarum led to overgrowth of coral reefs by several species of macroalgae including representatives of the genera Dictyota, Lobophora, Padina, Halimeda and Chaetomorpha (Carpenter 1990, Done 1992, Hughes 1994). Some Tahitian reefs have been overgrown by Turbinaria ornata and Sargassum mangaravense since the late 1980s with no direct evidence for causality (Stiger \& Payri 1999a,b). On the Great Barrier Reef, much of the shallow reef flats have been dominated by macroalgae since the mid-1980s, mainly Sargassum spp. and Lobophora variegata (Done 1992, McCook 1997). While nutrients and/or sedimentation may enhance the success and abundance of these algal species, a preponderance of studies suggest that herbivory is more important in regulating biomass (McCook 1999, McCook et al. 2001 and references therein). The case studies above further illustrate the diversity of algal genera involved in phase shifts across the tropics and also highlight the lack of recovery or reversal back to coral dominance in these systems.

In contrast to these well-documented phase shifts, the occurrence of ephemeral or episodic macroalgal blooms on tropical reefs is not well documented. Ephemeral or seasonal algal blooms are common in temperate coastal regions and in lakes, streams and agricultural drainage systems (Morand \& Briand 1996, Valiela et al. 1997, Raffaelli et al. 1998). Blooms generally occur when 1 or more limiting resources suddenly become available, leading to rapid algal growth. Once the resource has been exhausted or light levels are sufficiently reduced, the bloom generally senesces quickly (Raffaelli et al. 1998). These ephemeral blooms usually involve 1 or more species of early successional, opportunistic green algae from the genera Ulva, Enteromorpha, Chaetomorpha or Cladophora (Dodds \& Gudder 1992, Valiela et al. 1997, Raffaelli et al. 1998, Lotze \& Schramm 2000, Taylor et al. 2001).

The proliferation of 1 or more of these green algal genera in a given area is often linked to eutrophication, where either nitrogen or phosphorus is the limiting nutrient (Duarte 1995, Valiela et al. 1997, Raffaelli et al. 1998). Ulva and Cladophora can outcompete phytoplankton when nutrient concentrations in the water column are sufficiently high (Thybo-Christesen et al. 1993, Ravera 2000). The success of these opportunistic green algae can also be attributed to a number of other physiochemical factors including high photosynthetic rates, high surface area to volume ratios, ability to use $\mathrm{HCO}_{3}$, and tolerance to a wide range of temperatures, salinities, irradiance and hostile chemical environments (Raffaelli et al. 1998, Taylor et al. 2001).

Some well-documented examples of temperate ephemeral algal blooms include Ulva rigida in the marine lagoons of Venice (Runca et al. 1996, Ravera 2000), Cladophora glomerata both in lakes in Germany (Ensminger et al. 2000) and in coastal environments in the Baltic Sea (Paalme et al. 2002), C. albida in the Peel-Harvey Estuarine System in western Australia (Birch et al. 1981), C. sericea in shallow Danish bays (Thybo-Christesen et al. 1993), and C. vagabunda in Waquoit Bay, Massachusetts, USA (Peckol et al. 1994). In the tropics, specifically on the reefs around Bermuda, C. prolifera has formed nuisance blooms for several decades, but these are generally persistent and occur in protected, shallow, nearshore environments 
(Bach \& Josselyn 1978, 1979, Lapointe \& O'Connell 1989). In southeast Florida the green alga Codium isthmocladum has been growing excessively in deep water for some time; proliferation of this species has been blamed on deep offshore sewage seeps (Lapointe 1997). Given the lack of documented cases, it is unclear if ephemeral green algal blooms are truly uncommon in tropical marine ecosystems or if they have simply been overlooked.

Since the mid-1980s, the coral reefs of West Maui, Hawai'i, have experienced episodic blooms of the green alga Cladophora sericea. Six of these events have been cataloged with underwater photography (www.turtles.org/whoswho.htm). Blooms generally occur during the summer months, with initial signs of the alga appearing around April. Over time, the alga becomes more prolific and usually peaks in abundance around July-August; by October most of the bloom is gone. Because of the unpredictable nature of such events, very little research has been conducted on $C$. sericea in Hawai'i. However, when blooms are under way, their magnitude is such that the filamentous green alga grows from shore to depths greater than $30 \mathrm{~m}$ and is so prolific that beaches in the popular tourist areas become inundated with rotting biomass. This bloom-forming alga appears to smother the benthos, including coral-dominated areas, and may contribute to a decline in coral cover over time (S. Hau, Hawaii Department of Land and Natural Resources, pers. comm.).

As there are links reported between inorganic nutrients and green algal blooms in other regions, we wanted to determine if such relationships could be established between the abundance of Cladophora sericea, its physiology and ambient nutrient levels. Nutrient-rich groundwater has been posited as a potential factor influencing bloom formation on West Maui. However, due to the ephemeral and unpredictable timing of these blooms, data collection prior to this study has been largely unsuccessful. Our specific goals were to characterize the nutrient environment, macroherbivore community structure and the physiological characteristics of $C$. sericea in situ during a bloom event, and to examine the response of this alga to nutrient enrichment in the field and laboratory.

\section{MATERIALS AND METHODS}

Field assessments. Site description: All fieldwork and sample collection was performed using SCUBA at Kahekili Beach Park (KBP; 21⒌201' N, $156^{\circ} 41.557^{\prime} \mathrm{W}$ ) on the southwest side of the island of Maui, Hawai'i (Fig. 1A-C), from 9 to 11 July 2001. Land use of the area surrounding KBP includes resort landscaping and fertilizer application, septic systems, an urban sewage treatment facility with 4 injection wells (pumping at 15 to 25 million $1 \mathrm{~d}^{-1}$ ), pineapple agriculture, and golf courses, all of which may introduce nutrients into the nearshore environment via groundwater intrusion and/or surface runoff (see Fig. 1C). Offshore, the coral reef begins at about $2 \mathrm{~m}$ depth and gradually slopes to $\sim 10 \mathrm{~m}$, where a rubble zone starts and eventually turns to sand (Jokiel et al. 2004). The rhizophytic (sand-dwelling) green alga Halimeda incrassata dominates much of this sandy substratum from approximately 10 to $>40 \mathrm{~m}$ (see Fig. 1C).

Benthic surveys: At KBP, surveys were conducted at $3,9,15,25$, and $34 \mathrm{~m}$ depths. At each depth, two $30 \mathrm{~m}$ transects were randomly selected and placed parallel to shore. Ten randomly selected $0.25 \mathrm{~m}^{2}$ quadrats were surveyed on each transect. Percent cover of all benthic organisms was visually estimated in each quadrat.

Macroherbivore surveys: Abundance of herbivorous fish was quantified along the same $30 \mathrm{~m}$ belt transects $(n=2)$ at all depths, where all individuals were enumerated within $1 \mathrm{~m}$ of either side of the line. To examine patterns in abundance across the depth gradient, species were pooled into respective families (Acanthuridae or Scaridae). Sea urchin abundance was determined along the two $30 \mathrm{~m}$ transects, where all individuals were counted within six $5 \times 1 \mathrm{~m}$ strips on alternating sides of transects.

Water sampling: At each site, both ambient water column samples and sediment porewater samples were collected in triplicate. Ambient water samples were collected approximately $0.5 \mathrm{~m}$ from the substratum using sterile $140 \mathrm{ml}$ syringes. Underwater, syringes were rinsed with sample water 3 times before final collection. Sediment porewater samples were collected using a method based on Falter \& Sansone (2000) modified for rapid collection using SCUBA. Samples were collected by driving an $800 \mathrm{~mm}$ long, $5 \mathrm{~mm}$ wide, stainless steel tube $0.25 \mathrm{~m}$ into the substratum. The tube was tapered closed at one end and ground to a sharp edge that was perforated with sixteen $1.5 \mathrm{~mm}$ diameter holes to enable sediment porewater to flow into the tube. The tube was simply driven into the substratum to a depth of $0.25 \mathrm{~m}$. Porewater was then drawn out of the tube using silicon tubing, $140 \mathrm{cc}$ syringes and a 3-way valve. The volume of the tube was evacuated twice before the final sample was retained in the syringe to ensure a representative sample was drawn. After collection, all water samples were returned to the surface, where a $20 \mathrm{ml}$ aliquot was filtered through Whatman \#2 GF/F glass fiber filters and rinsed into $60 \mathrm{ml}$ Nalgene sample bottles; bottles were rinsed 3 times with sample water. Finally, the remaining $60 \mathrm{ml}$ of sample was filtered into sample bottles and placed immediately on ice. All samples were 

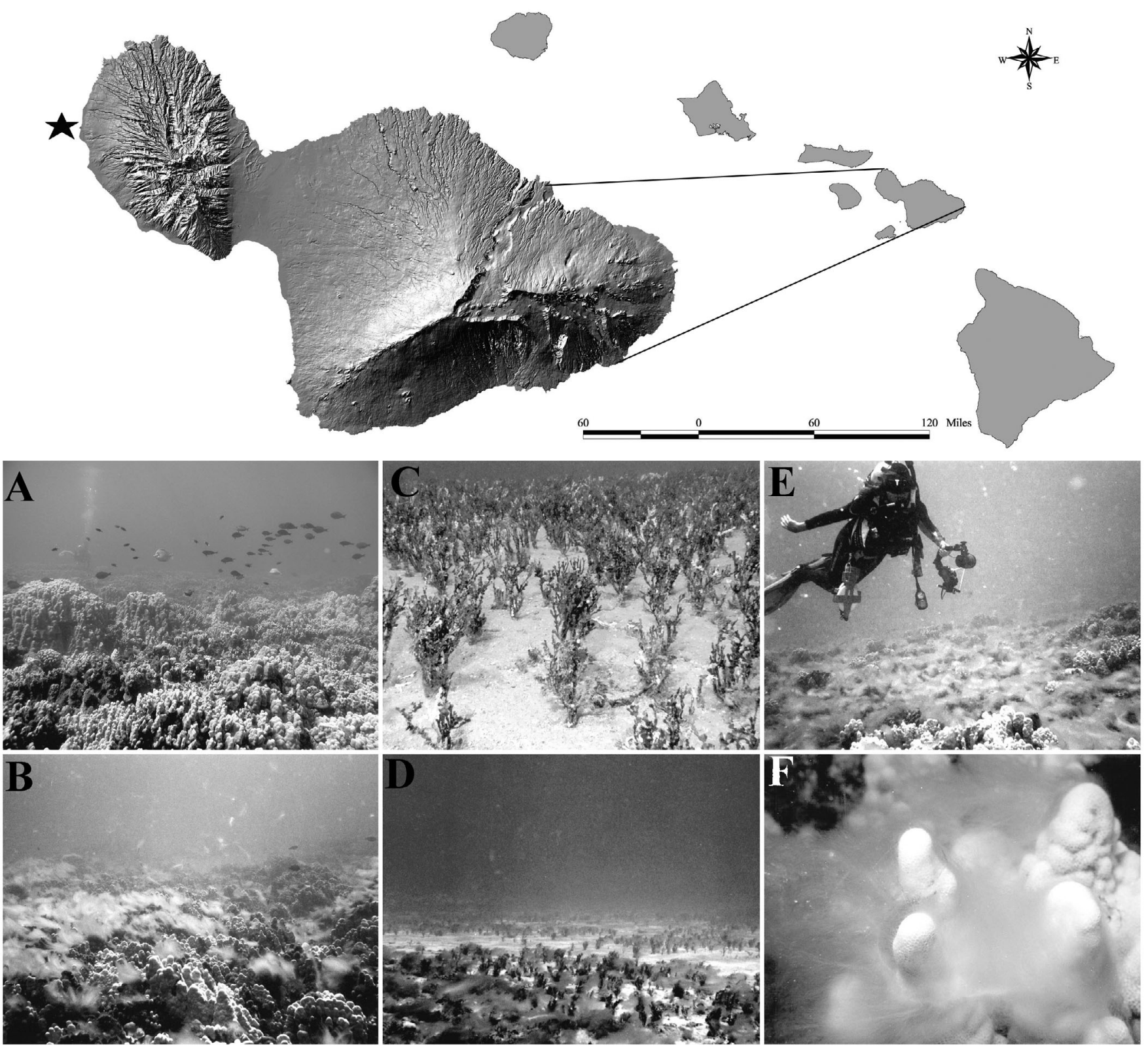

Fig. 1. Upper panel: Map of the Hawaiian Islands and close-up of Maui Island; star indicates the location of Kahekeli Beach Park (KBP). Lower panel: (A) Reef community during a non-bloom year at $9 \mathrm{~m}$, (B) the same area during the $2001 \mathrm{bloom}$, (C) the rhizophytic green alga Halimeda incrassata forming meadows at the 15, 25, $34 \mathrm{~m}$ sites during a non-bloom year, (D) the same area during the 2001 bloom, (E) SCUBA diver working at the $9 \mathrm{~m}$ site during the 2001 bloom, and (F) Cladophora sericea snagged on the massive coral Porites lobata. 1 mile $=\sim 1.6 \mathrm{~km}$

frozen upon return to shore. Concentrations of silicate, nitrate, nitrite, ammonium, and phosphate were determined using a Technicon Model AAII autoanalyzer, and salinity was determined with a handheld YSI conductivity probe.

In situ nutrient enrichment experiments: A nutrient enrichment study was performed on samples of Cladophora sericea in situ to determine if the alga was nutrient limited across depths and to assess whether it would respond to short-term nutrient enrichments. At each site, 6 C. sericea samples of approximately the same size (1 to $2 \mathrm{~g}$ wet weight) were collected and placed into plastic mesh pouches affixed to 2 weighted PVC rods (length $=500 \mathrm{~mm}$, diameter $=12 \mathrm{~mm}$ ). These rods were placed horizontally across the benthos. Three samples served as controls while the remaining 3 received a nutrient enrichment treatment. Enrichment was achieved by placing $20 \mathrm{~g}$ of the commercial 
fertilizer Osmocote (NPK ratio: 19-6-12) into cheesecloth bags; these bags were then attached to PVC rods adjacent to the mesh sample pouches. The pouches were affixed prior to entering the water and temporarily covered with plastic film to ensure that nutrient did not leak out until the experiment began. Control samples were placed at least $5 \mathrm{~m}$ away from the enriched samples to prevent cross contamination, and all were left unmanipulated for $24 \mathrm{~h}$. Water samples were collected as described above for enriched samples (syringes were positioned $\sim 10 \mathrm{~cm}$ from enrichment source) after the $24 \mathrm{~h}$ period to quantify enrichment.

In situ chlorophyll fluorescence measurements: Twenty-four hours after enrichment, divers assessed nutrient-limited status by examining fluorescence parameters in situ using a pulse amplitude modulation (PAM) fluorometer with a red measuring light (DivingPAM, Walz). Photosynthetic parameters were determined by performing rapid light curves (RLCs) on all samples, where an RLC consisted of a series of saturating pulses applied after $10 \mathrm{~s}$ exposures to actinic irradiance of increasing intensity (White \& Critchley 1999). RLCs were performed on light-acclimated material that was darkened prior to measurement for 15 to $20 \mathrm{~s}$ to minimize the influence of energy-dependent nonphotochemical quenching (Schreiber et al. 1997, Ralph et al. 1998). The maximum actinic irradiance was $\sim 800 \mu \mathrm{mol}$ quanta $\mathrm{m}^{-2} \mathrm{~s}^{-1}$ photosynthetically active radiation (PAR). Each saturating pulse provided an estimate of the effective quantum yield $\left(\Delta F / F_{\mathrm{m}}{ }^{\prime}=\right.$ $\left.\left(F_{0}{ }^{\prime}-F_{\mathrm{m}}{ }^{\prime}\right) / F_{\mathrm{m}}{ }^{\prime}\right)$, where $\Delta F$ is the difference between the maximum $\left(F_{\mathrm{m}}\right)$ and minimum $\left(F_{0}\right)$ fluorescence values. Relative electron transport rate (rETR) was calculated, where $\Delta F / F_{\mathrm{m}}$ ' was multiplied by the actinic PAR of the $10 \mathrm{~s}$ interval preceding the pulse; no correction for absorptance or PSII-PSI allocation was made as accurate in situ measurement of the former was impractical and the latter was unknown.

Tissue samples: At each depth 5 samples of Cladophora sericea were haphazardly collected for tissue nutrient analysis. Divers collected and placed individual samples into separate labeled Ziploc bags. After transport on ice to the laboratory at the University of Hawai'i, they were rinsed briefly in deionized water, blotted dry, and weighed. Samples were then oven dried at $60^{\circ} \mathrm{C}$ until a constant weight was reached and then ground with a mortar and pestle or ball-mill (WigL-Bug, Crescent Dental). Carbon and nitrogen content (\%) and stable isotope composition $\left({ }^{15} \mathrm{~N}:{ }^{14} \mathrm{~N}\right.$ and ${ }^{13} \mathrm{C}:{ }^{12} \mathrm{C}$ ) were determined using a Carla Erba NC2500 Elemental Analyzer and a Finnigan MAT ConFloII system. Phosphorus content was determined using a Perkin-Elmer 6500 ICP spectrophotometer.

Laboratory nutrient enrichment experiment. Sample collection: A nutrient enrichment study was con- ducted in the laboratory to assess the growth and physiology of Cladophora sericea in response to elevated nutrients. Samples of C. sericea were collected from KBP on 11 July 2001 and placed in 81 Ziploc bags. Bags were placed in an insulated cooler and immediately transported to the laboratory. Maximum transport time was approximately $3 \mathrm{~h}$. Samples were then immediately transferred into new seawater in 1.51 glass beakers with aeration and natural lighting (maximum midday irradiance was $\sim 560 \mu \mathrm{mol}$ quanta $\mathrm{m}^{-2} \mathrm{~s}^{-1}$ ).

The nutrient enrichment experiment consisted of 4 nutrient treatments $\left(20 \mu \mathrm{M} \mathrm{NO}_{3}, 2 \mu \mathrm{M} \mathrm{PO}_{4}, 20 \mu \mathrm{M}\right.$ $\mathrm{NO}_{3}+2 \mu \mathrm{MPO}_{4}$, and Osmocote: $\mathrm{NH}_{4}=3.33 \mu \mathrm{M}, \mathrm{NO}_{3}=$ $7.03 \mu \mathrm{M}, \mathrm{PO}_{4}=1.94 \mu \mathrm{M}$ ) and a control. All stock solutions were made with reagent grade nutrients. Seawater used in this experiment was obtained from the Waikiki Aquarium facility and was initially sand filtered and then further filtered through $2 \mu \mathrm{m}$ glass-fiber filters. Samples of Cladophora sericea were weighed and randomly assigned to 1 of 5 treatments with 3 replicates per treatment. The entire experiment was conducted in a greenhouse with natural lighting. Each algal sample was grown in a flow-through system in individual 1.51 glass beakers, and treatments were administered from holding containers to beakers via constant flow peristaltic pumps (flow rate $=1 \mathrm{ml} \mathrm{min}^{-1}$ ). The experiment was maintained at constant temperature $\left(25^{\circ} \mathrm{C}\right)$ using a constant flow water bath that surrounded the base of the beakers and ran for $7 \mathrm{~d}$.

Variables measured: Growth was calculated for all samples from the beginning to the end of the experiment and expressed as percent increase in wet wt $\mathrm{d}^{-1}$. At the end of the experiment, tissue percent carbon, nitrogen, phosphorus, $\delta^{15} \mathrm{~N}$, and $\delta^{13} \mathrm{C}$ were determined for all samples as discussed above. Photosynthetic parameters were assessed by conducting RLCs using PAM fluorometry. The maximum quantum yield of chlorophyll fluorescence $\left(F_{\mathrm{v}} / F_{\mathrm{m}}\right)$ was determined by dark-acclimating algal material for 10 min using plastic clips (Walz) prior to administering a saturating pulse (800 ms, 8000 $\mu \mathrm{mol}$ quanta $\mathrm{m}^{-2} \mathrm{~s}^{-1}$ ). These treatments enabled measurements of $F_{0}$ and $F_{\mathrm{m}}$ from which the term $\left(F_{0}-F_{\mathrm{m}}\right) / F_{\mathrm{m}}=F_{\mathrm{v}} / F_{\mathrm{m}}$ was calculated (nomenclature according to van Kooten \& Snell 1990). Chlorophyll $a$ and $b$ content was determined spectrophotometrically using $1.0 \mathrm{ml}$ dimethylformamide (DMF) as solvent (Moran \& Porath 1980). This technique ensured minimal loss of tissue.

Data analysis: Most field data sets were analyzed using 1-way analysis of variance (ANOVA) with depth as a fixed factor. A 2-way ANOVA was used for the field nutrient enrichment experiment with depth and nutrient enrichment both as fixed factors. All data were tested for homogeneity of variance prior to running analyses and, when necessary, log-transformed. 
Tukey's post hoc comparisons were used to test for differences among levels of significant factors; differences are described as significant if $p<0.05$. RLC data were described using non-linear least-squares regression techniques and the model by Platt et al. (1980). The parameters rETR $_{\max }$ (maximum rETR), alpha (the slope of the lightlimited region of the curve), and $E_{k}$

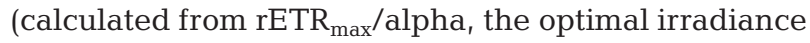
for maximal electron transport) were derived from these curves. ANOVAs were performed using Minitab version 13.0, and nonlinear regression analysis was conducted with SigmaPlot version 8.0.

\section{RESULTS}

\section{Field assessments}

The green alga Cladophora sericea formed a conspicuous bloom on the reefs of West Maui during the summer of 2001 (Fig. 1). The alga occurred from shore to greater than $34 \mathrm{~m}$ depth but was significantly more abundant at $9 \mathrm{~m}(F=9.74, \mathrm{p}<0.001,42 \%$ cover \pm 5.93 , $1 \mathrm{SE}$ ) than at any of the other depths surveyed (Fig. 2). Coral cover was highest at 3 and $9 \mathrm{~m}$ but was sparse at $15 \mathrm{~m}$ and absent from the 25 and $34 \mathrm{~m}$ sites (Fig. 2). Sand and the rhizophytic alga Halimeda incrassata dominated the benthos at deeper depths (Figs. 1 \& 2). In general there were no patterns between the abun-

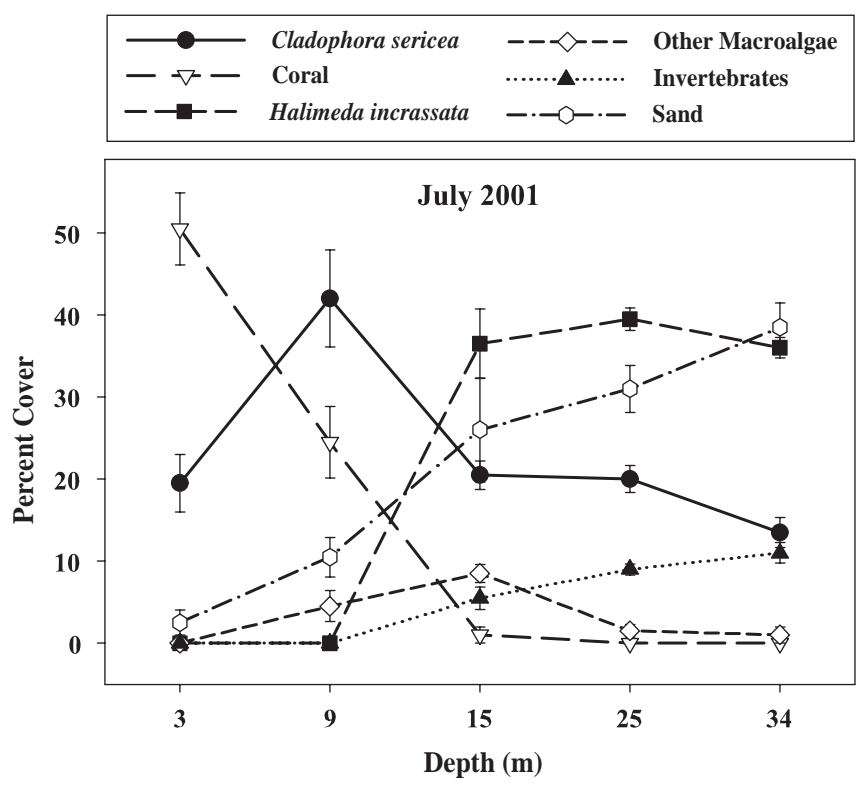

Fig. 2. Results of benthic surveys from the 5 sites $(3,9,15,25$, $34 \mathrm{~m}$ depth) showing abundance of the 5 most common benthic organisms (coral species and macroalgae were lumped into broad categories for ease of comparison); values are means of 10 quadrats sampled on each of 2 transects \pm 1 SE

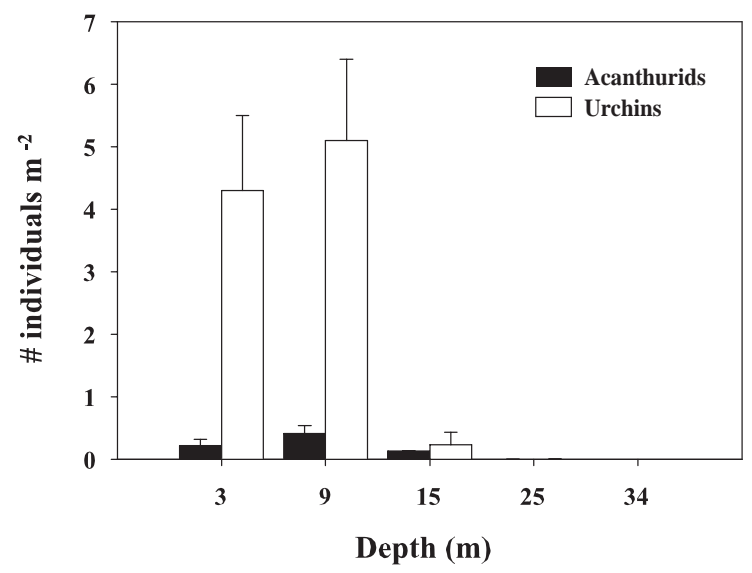

Fig. 3. Macroherbivore abundance (acanthurids and urchins) from 5 depths $(3,9,15,25,34 \mathrm{~m})$ at Kahekili Beach Park $($ mean $+1 \mathrm{SE})$

dance of C. sericea and that of other benthic organisms (Fig. 2); the alga was found attached to the benthos, drifting in the water column and snagged on top of various substratum types including live coral and other macroalgae (Figs. $1 \& 2$ ). Results of the benthic surveys show that during a bloom $C$. sericea occurred from $3 \mathrm{~m}$ to greater than $34 \mathrm{~m}$ depth with an average abundance of $23.1 \%$ cover $( \pm 2.01,1 \mathrm{SE})$.

Herbivorous fish and sea urchins were most abundant on the reef at the 3 and $9 \mathrm{~m}$ depths (Fig. 3). Acanthurids (surgeonfish) comprised the majority of large mobile herbivorous fish communities. The most abundant sea urchin was Tripneustes gratilla followed by Echinometra mathei (data not shown). Very few macroherbivores were found at the deeper depths $(15$, 25 and $34 \mathrm{~m}$ ) in the Halimeda incrassata meadows. In general, herbivores were most abundant at sites where C. sericea abundance was also high (3 and 9 m, Figs. 2 \& 3).

Nutrient concentrations in the water column were low. While there was a trend of decreasing nutrient concentrations with distance from shore (or depth), concentrations were not significantly different among depths (Fig. 4, Table 1). In contrast, concentrations of nutrients in sediment porewater were significantly different between depths and in relation to the water column nutrient concentrations (Fig. 4). Phosphate concentration in the porewater was significantly higher at the 2 deeper sites ( 25 and $34 \mathrm{~m}$ ) followed by a declining onshore-to-offshore trend with $3 \mathrm{~m}$ greater than $9 \mathrm{~m}$ and $15 \mathrm{~m}$. Silicate concentration was high at all depths but was greatest at $15 \mathrm{~m}$ (minimum: $128.0 \mu \mathrm{M}$, maximum: $141.9 \mu \mathrm{M})$. Salinity of porewater was lowest at the 9 and $15 \mathrm{~m}$ sites, with samples as low as $20 \%$. Ammonium concentration was highest at the $9 \mathrm{~m}$ site, reaching values as high as $22 \mu \mathrm{M}$, and was 

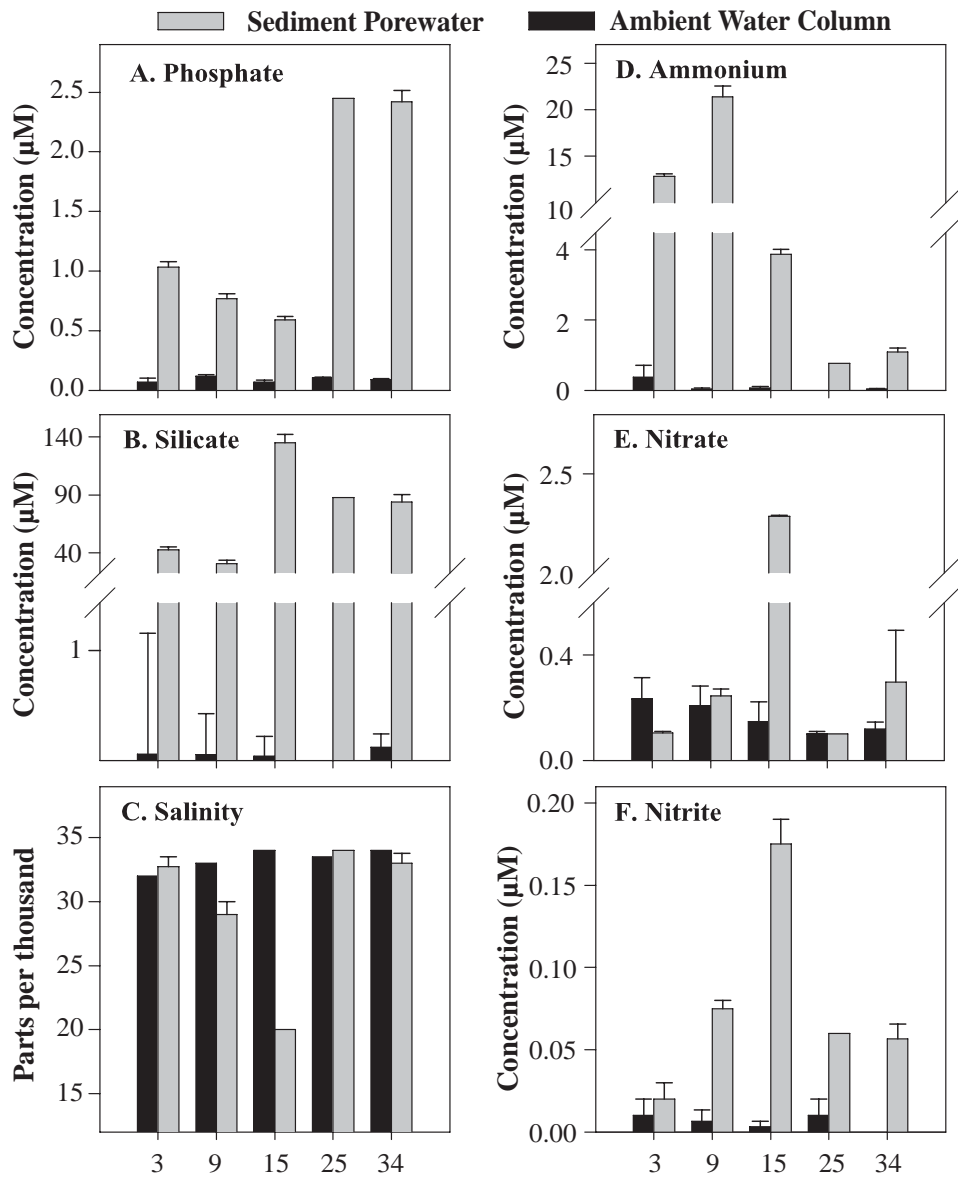

Depth (m)

Fig. 4. Water chemistry results for both ambient water column samples and sediment porewater samples collected from 5 different depths (3, 9, 15, 25, 34 m) at Kahekili Beach Park on 11 July 2001; values are means $+1 \mathrm{SE}, \mathrm{n}=3$ nificantly different among any of the depths sampled. However, $\mathrm{rETR}_{\max }$ did significantly increase with nutrient enrichment overall, suggesting that $C$. sericea was nutrient limited in the field (Fig. 6A, Table 2). Further, the greatest increases in response to nutrient treatments in situ were observed in samples from the 2 deepest depths, 25 and $34 \mathrm{~m}$. A significant interaction was found for alpha between depth and nutrient enrichment treatments, indicating that algae at the different depths varied in their response to enrichment with deeper samples, again showing the largest increase (Fig. 6B, Table 2). There were no significant site or treatment effects detected for saturating irradiance (Fig. 6C, Table 2).

Tissue nutrient analyses of Cladophora sericea from fieldcollected samples along a depth gradient showed variable results by nutrient (Table 3, Fig. 7). Percent tissue carbon was variable but not statistically significant among depths. $\delta^{13} \mathrm{C}$ signatures were also variable across depth but were least negative for the 3 and $34 \mathrm{~m}$ sites. Both percent tissue nitrogen and $\delta^{15} \mathrm{~N}$ were highest at the shallower depths and generally decreased with depth; however, there was an increase in value and variability at the $34 \mathrm{~m}$ site. No significant differences were found for percent tissue phosphorus among depths, but variance was highest at shallow and deep locations. C:N ratios were lowest for algae growing close to shore (at the $3 \mathrm{~m}$ site) and highest at $15 \mathrm{~m}$. much lower at deeper depths. Nitrate and nitrite concentrations showed similar patterns, with the highest concentrations at $15 \mathrm{~m}$. Total dissolved inorganic nitrogen (DIN) from water column samples showed a declining onshore-to-offshore pattern, with highest concentrations at shallow depths (Fig. 5); porewater DIN concentrations were highest at $9 \mathrm{~m}$.

Nutrient enrichment with Osmocote in the field led to significantly elevated concentrations of DIN and phosphate compared to ambient levels ( $T$-test results: DIN: $t=-2.93, \mathrm{p}=0.01$, enriched: $1.2 \mu \mathrm{M} \pm 0.29 \mathrm{SE}$, control: $0.27 \mu \mathrm{M} \pm 0.08 \mathrm{SE}_{;} \mathrm{PO}_{4}: t=-2.28, \mathrm{p}=$ 0.03, enriched: $0.27 \mu \mathrm{M} \pm 0.017 \mathrm{SE}$, control: $0.08 \mu \mathrm{M} \pm 0.009 \mathrm{SE}) \cdot \mathrm{rETR}_{\max }$ for Cladophora sericea were not sig-
Table 1. Results of 1-way ANOVA for water chemistry parameters (df for all tests $=4)$. Site (depth) is the experimental factor; Tukey's multiple comparisons were used to test for differences among the depths when a significant effect was detected. Bold values indicate significance at the alpha $=0.05$ level $_{i}$ ns: not significant

\begin{tabular}{|c|c|c|c|c|}
\hline Parameter & MS & $F$ & $\mathrm{p}$ & Multiple comparisons \\
\hline \multicolumn{5}{|c|}{ Water column } \\
\hline $\mathrm{PO}_{4}$ & 0.418 & 0.94 & 0.482 & ns \\
\hline $\mathrm{SiO}_{4}$ & 0.048 & 1.20 & 0.376 & ns \\
\hline $\mathrm{NO}_{3}$ & 0.319 & 0.64 & 0.645 & ns \\
\hline $\mathrm{NO}_{2}$ & 0.0041 & 0.41 & 0.799 & ns \\
\hline $\mathrm{NH}_{4}$ & 0.404 & 0.93 & 0.489 & ns \\
\hline \multicolumn{5}{|l|}{ Porewater } \\
\hline $\mathrm{PO}_{4}$ & 0.857 & 180.22 & $<0.001$ & $34 \mathrm{~m}, 25 \mathrm{~m}>3 \mathrm{~m}>9 \mathrm{~m}>15 \mathrm{~m}$ \\
\hline $\mathrm{SiO}_{4}$ & 0.699 & 56.48 & $<0.001$ & $\begin{array}{l}15 \mathrm{~m}>34 \mathrm{~m}, 3 \mathrm{~m}, 9 \mathrm{~m} \\
34 \mathrm{~m}, 25 \mathrm{~m}>3 \mathrm{~m}, 9 \mathrm{~m}\end{array}$ \\
\hline $\mathrm{NO}_{3}$ & 1.74 & 37.23 & 0.001 & $15 \mathrm{~m}>$ all \\
\hline $\mathrm{NO}_{2}$ & 1.37 & 8.62 & 0.018 & $15 \mathrm{~m}>3 \mathrm{~m}$ \\
\hline $\mathrm{NH}_{4}$ & 4.05 & 255.48 & $<0.001$ & $9 \mathrm{~m}>3 \mathrm{~m}>15 \mathrm{~m}>25 \mathrm{~m}, 34 \mathrm{~m}$ \\
\hline Salinity & 64.72 & 48.85 & $<0.001$ & $15 \mathrm{~m}<$ all \\
\hline
\end{tabular}




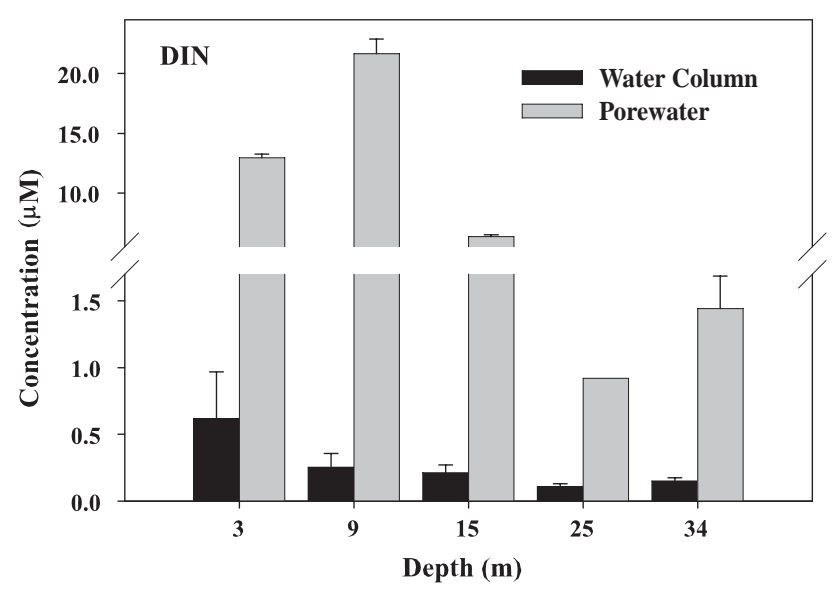

Fig. 5. Total dissolved inorganic nitrogen (DIN) concentrations for water column and porewater samples collected at 5 depths $(3,9,15,25,34 \mathrm{~m})$ at Kahekili Beach Park on 11 July 2001; values are means $+1 \mathrm{SE}, \mathrm{n}=3$

Several positive associations were found between water column DIN and Cladophora sericea parameters (Fig. 8A-D). The most variable of these relationships was between percent cover of C. sericea and DIN, where most of the variability could be attributed to the low percent cover at $3 \mathrm{~m}$. The $3 \mathrm{~m}$ location was, however, the site where extensive $C$. sericea biomass was observed drifting unattached to the bottom where benthic percent cover was likely an underestimate of true biomass production. Percent tissue nitrogen $\delta^{15} \mathrm{~N}$ and $\mathrm{rETR}_{\max }$ were all positively associated with water column DIN. The relationships between algal parameters and porewater DIN were also positive but were more variable (Fig. 8E-H).

Table 2. Results of 2-way ANOVA for photosynthetic parameters of Cladophora sericea following in situ nutrient enrichment with depth $(3,9,15,25,34 \mathrm{~m})$ and enrichment both as fixed factors. Bold values indicate significance at the alpha $=0.05$ level. rETR $_{\max }$ : maximum electron transport rate; Alpha: photosynthetic efficiency; $E_{k}$ : saturating irradiance

\begin{tabular}{|lcccc|}
\hline Parameter & df & MS & $F$ & $\mathrm{p}$ \\
\hline rETR $_{\text {max }}$ & & & & \\
$\quad$ Site & 4 & 203 & 0.92 & 0.471 \\
Treatment & 1 & 998 & 4.54 & $\mathbf{0 . 0 4 6}$ \\
Interaction & 4 & 68 & 0.31 & 0.869 \\
Alpha & & & & \\
Site & 4 & 0.00057 & 1.82 & 0.165 \\
Treatment & 1 & 0.00021 & 0.67 & 0.422 \\
Interaction & 4 & 0.00135 & 4.33 & $\mathbf{0 . 0 1 1}$ \\
$E_{k}$ & & & & \\
Site & 4 & 1957 & 1.37 & 0.280 \\
Treatment & 1 & 4912 & 3.44 & 0.077 \\
Interaction & 4 & 629 & 0.44 & 0.780 \\
\hline
\end{tabular}

\section{Laboratory nutrient enrichment experiment}

Summary statistics for all of the growth and physiological parameters measured for Cladophora sericea following the nutrient enrichment experiment are shown in Table 4, and the results of 1-way ANOVAs are shown in Table 5. Growth was significantly greater in the Osmocote treatment than for any of the other treatments (Fig. 9). None of the fluorescence parameters showed significant responses to the enrichment treatments except for $F_{\mathrm{v}} / F_{\mathrm{m}}$ (dark acclimated), which was significantly higher for Osmocote treated samples than any other treatment, and both nitrogen and phosphorus treated samples had higher yield values than controls (Fig. 10). Nevertheless, all of the measured fluorescence parameters showed trends of increased response with enrichment. Concentrations of tissue nutrients and photosynthetic pigments (chl $a, b$ and carotenoids) increased in response to enrichment; Osmocote treated samples showed the greatest overall increase (Tables 4 \& 5).
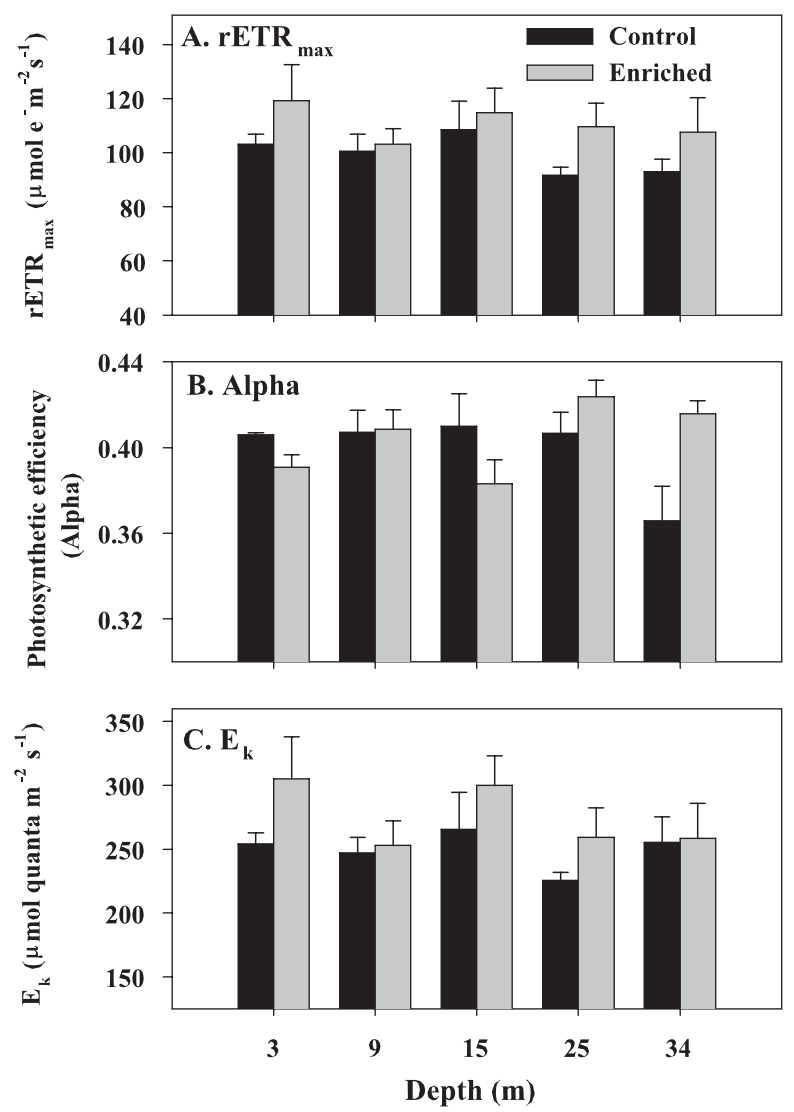

Fig. 6. Pulse amplitude modulation fluorometry results following 24 nutrient-enrichment in situ for Cladophora sericea; values are means $+1 \mathrm{SE}, \mathrm{n}=3 . \mathrm{rETR}_{\max }$ : maximum relative electron transport rate; $E_{k}$ : saturating irradiance 
Table 3. Results of 1-way ANOVA for Cladophora sericea tissue nutrient concentrations with depth $(3,9,15,25,34 \mathrm{~m})$ as the factor (df for all tests $=4$ ); Tukey's multiple comparisons were used to test for differences among depths. Bold values indicate significance at the alpha $=0.05$ level; ns: not significant

\begin{tabular}{|lcrrc|}
\hline Parameter & MS & $F$ & $\mathrm{p}$ & Multiple comparisons \\
\hline$\% \mathrm{C}$ & 2.05 & 0.270 & 0.888 & $\mathrm{~ns}$ \\
$\% \mathrm{~N}$ & 0.963 & 19.23 & $\mathbf{< . 0 0 1}$ & $3 \mathrm{~m}>$ all \\
$\% \mathrm{P}$ & 0.361 & 2.14 & 0.151 & $\mathrm{~ns}$ \\
$\delta^{13} \mathrm{C}$ & 4.28 & 6.64 & $\mathbf{0 . 0 0 7}$ & $3 \mathrm{~m}>9 \mathrm{~m}, 15 \mathrm{~m}$ \\
$\delta^{15} \mathrm{~N}$ & 8.63 & 7.61 & $\mathbf{0 . 0 0 4}$ & $3 \mathrm{~m}>15 \mathrm{~m}, 25 \mathrm{~m}, 34 \mathrm{~m}$ \\
$\mathrm{C}: \mathrm{N}$ & 67.39 & 16.30 & $\mathbf{< . 0 0 1}$ & $3 \mathrm{~m}<\mathrm{all}$ \\
$\mathrm{N}: \mathrm{P}$ & 12.03 & 0.72 & 0.600 & $\mathrm{~ns}$ \\
& & & & \\
\hline
\end{tabular}

\section{DISCUSSION}

This study documents a large-scale ephemeral green algal bloom from a tropical coral reef environment. Various physiological and ecological characteristics of the bloom and associated parameters of water and sediment chemistry were characterized. The alga was abundant over a wide depth range, showed signs of nutrient limitation in the field as measured by in situ fluorescence, and responded significantly to nutrient enrichment in the laboratory. Water column nutrient concentrations were low and almost undetectable for all nutrients measured; these values were much higher for sediment porewater from the same field sites. Low levels of salinity and elevated silicate, nitrate, and ammonium concentrations in sediment porewater suggest that groundwater intrusion may be an important source of nutrients at this location. Herbivorous fish and sea urchin densities were highest at sites where Cladophora sericea was also most abundant, suggesting that grazing is not sufficient to control algal biomass at this location. While our data suggest that $C$. sericea may be using land-based nutrients in the field, other physical and/or biological factors are likely to be involved in bloom formation and senescence.

\section{Field characteristics}

Cladophora sericea occurred across a broad range in habitats but was most abundant on the reef at $9 \mathrm{~m}$ depth, where it was found growing on top of or entangled on other benthic organisms including reef-building corals (Figs. 1 \& 2). More importantly, the alga was highly abundant ( $>20 \%$ cover) at all depths surveyed, where even at $34 \mathrm{~m}$ there was no indication of a significant decline in abundance. The bloom also extended both up and down the coastline for several miles with Kahana at the northerly end and Lahaina at the southerly end of the distribution (data not shown); this had been reported from an adjacent island, Moloka'i, earlier in the year (E. Brown pers. comm.).

Results of water sampling at KBP suggest that groundwater seepage is occurring at this site. Low salinity, coupled with high nutrients from water sampled within sediment interstices, indicates a terrestrial source; in contrast, nutrient concentrations were very low for all water column samples. The very low salinity in samples taken from the 15 and $9 \mathrm{~m}$ depths and high silicate at all sites further suggest freshwater seepage via groundwater. Porewater nitrogen concentrations were highest at 3 , 9 , and $15 \mathrm{~m}$, while the phosphorus concentration was highest at the 25 and $34 \mathrm{~m}$ sites. These results illustrate that sampling the water column to determine nutrient concentration and rates of input to marine benthic
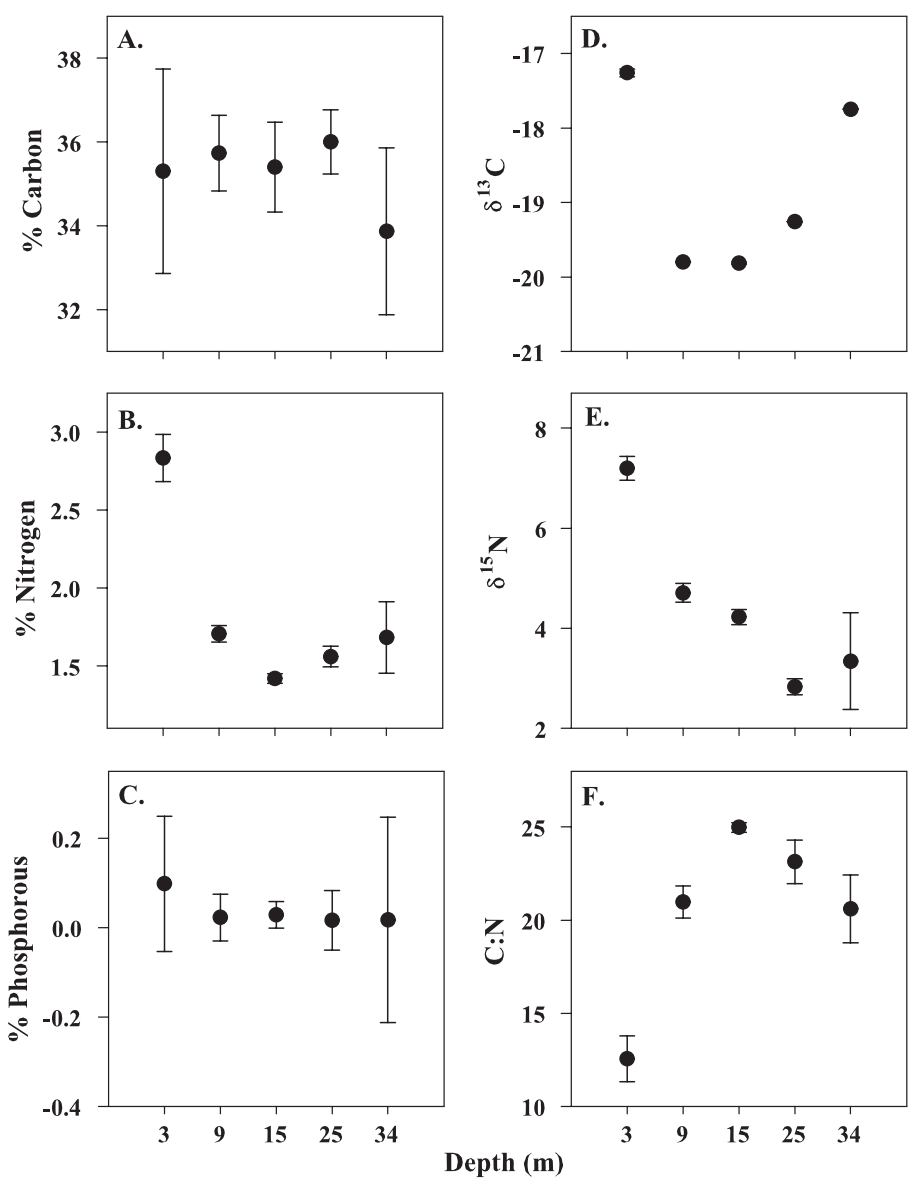

Fig. 7. Concentration of tissue nutrients: carbon, nitrogen, and phosphorus and the $\mathrm{C}: \mathrm{N}$ ratio as well as $\delta^{13} \mathrm{C}$ and $\delta^{15} \mathrm{~N}$ from Cladophora sericea collected along a depth gradient from the 5 depths $(3,9,15,25,34 \mathrm{~m})$ at Kahekili Beach Park; values are means $\pm 1 \mathrm{SE}, \mathrm{n}=3$ 


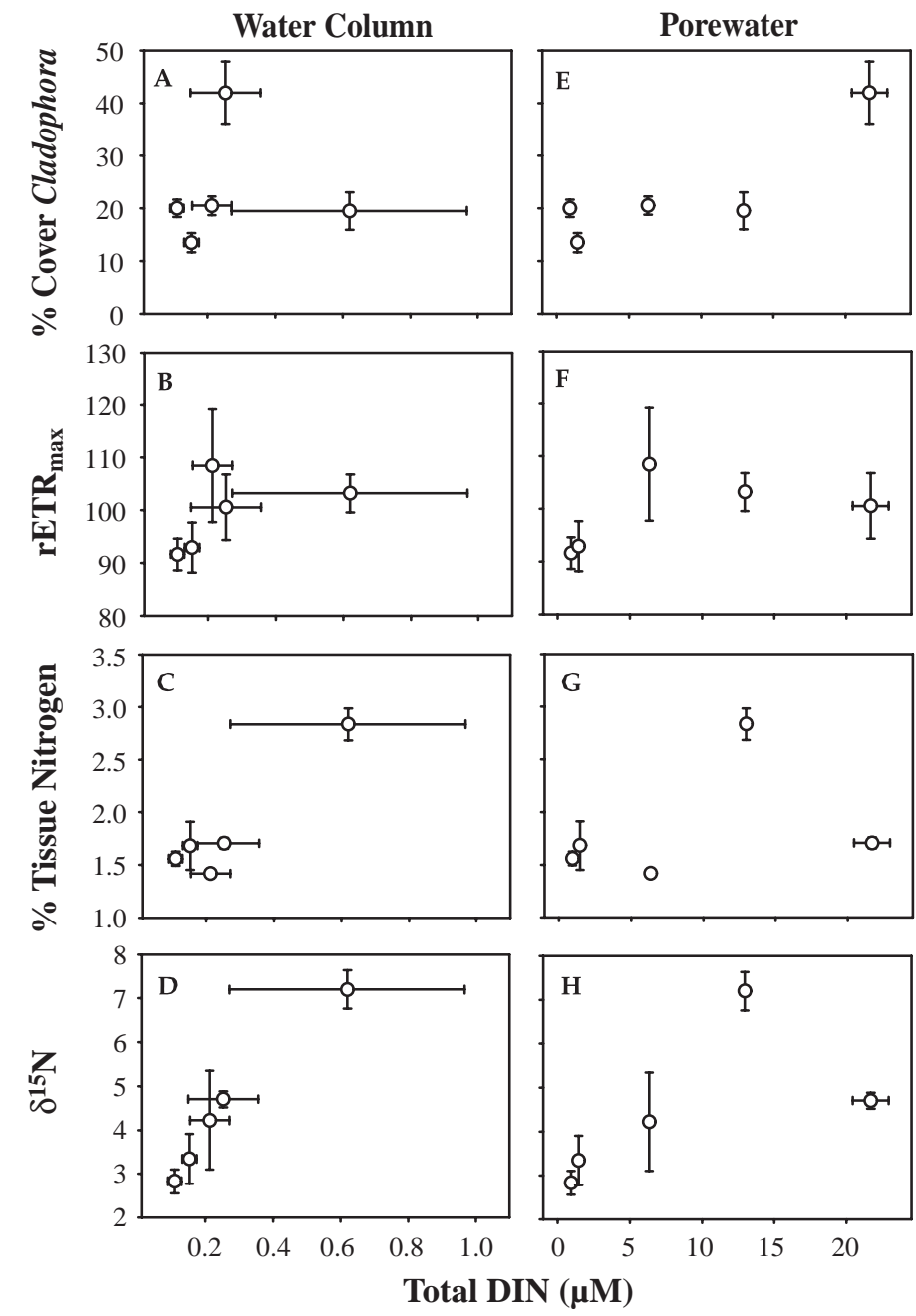

Fig. 8. Relationship between Cladophora sericea abundance and total dissolved inorganic nitrogen (DIN) concentrations for the water column $(\mathrm{A}-\mathrm{D})$ and the porewater $(\mathrm{E}-\mathrm{H})$ communities may be misleading especially in areas where macroalgae are abundant. Nutrient uptake rates by the algae may be such that any flux into the system will be masked by algal uptake, making detection nearly impossible from simple water column nutrient analysis (Umezawa et al. 2002a). While measurement of sediment porewater can be more informative than simply measuring water column nutrients, these static measures do not account for the flux of porewater out of the substratum. Flux from the sediment interstices is dependent on a number of other factors including sediment grain size and tidal pumping (Tribble et al. 1992), both of which are likely to be greater at the shallower sites. Thus the actual rate of porewater seepage into the water column and hence flux of nutrients may be greatest at the shallower sites, where algal biomass appeared to be greatest and tissue nitrogen was high.

Tissue nitrogen and $\delta^{15} \mathrm{~N}$ of Cladophora sericea was significantly higher at the $3 \mathrm{~m}$ site than at any of the other depths sampled. $\delta^{15} \mathrm{~N}$ values generally decreased with depth but increased and became more variable at the deepest site $(34 \mathrm{~m})$. The decrease in $\delta^{15} \mathrm{~N}$ with depth could be due to different sources of nitrogen at these locations (a dilution in land-based nutrients) or be related to different growth rates and metabolic activities of algae growing at these different sites (Cole et al. 2004). Faster growing samples, with high metabolic rates, would be assumed to have greater nitrogen requirements and hence not discriminate against ${ }^{15} \mathrm{~N}$ as much as slower growing algae (MacLeod \& Barton 1998). However, the increase in both $\delta^{15} \mathrm{~N}$ and percent tissue nitrogen at the deepest site suggests that an offshore nutrient source may be important in supporting this bloom (e.g. upwelling or internal tides; see

Table 4. Physiological parameters of Cladophora sericea in the laboratory nutrient-enrichment experiment (values are means $\pm 1 \mathrm{SE}) . F_{\mathrm{v}} / F_{\mathrm{m}}$ : maximum quantum yield of chlorophyll fluorescence; FW: fresh (wet) weight

\begin{tabular}{|c|c|c|c|c|c|}
\hline Variable & Control & $2 \mu \mathrm{M} P$ & $20 \mu \mathrm{M} \mathrm{NO}_{3}$ & $20 \mathrm{mM} \mathrm{NO}_{3}+2 \mu \mathrm{MPO}_{4}$ & Osmocote \\
\hline $\mathrm{rETR}_{\max }$ & $38.35(1.27)$ & $44.01(5.92)$ & $48.84(2.27)$ & $52.59(2.26)$ & $61.02(10.14)$ \\
\hline Alpha & $0.29(0.017)$ & $0.30(0.023)$ & $0.34(0.052)$ & $0.35(0.029)$ & $0.34(0.015)$ \\
\hline$E_{k}$ & $139.20(11.87)$ & $147.95(18.53)$ & $145.73(26.17)$ & $151.22(18.61)$ & $180.37(29.20)$ \\
\hline$F_{\mathrm{v}} / F_{\mathrm{m}}$ & $0.54(0.042)$ & $0.57(0.008)$ & $0.64(0.056)$ & $0.70(0.017)$ & $0.74(0.014)$ \\
\hline$\% \mathrm{C}$ & $38.07(0.041)$ & $38.39(0.36)$ & $34.84(0.58)$ & $38.27(0.092)$ & $37.50(0.33)$ \\
\hline$\% \mathrm{~N}$ & 4.28 (0.099) & $3.93(0.29)$ & $1.54(0.12)$ & $3.45(1.10)$ & $4.48(0.17)$ \\
\hline$\% \mathrm{P}$ & $0.069(0.007)$ & $0.081(0.005)$ & $0.072(0.007)$ & $0.098(0.008)$ & $0.066(0.003)$ \\
\hline$C: N$ & $8.90(0.024)$ & 9.77 (3.74) & $24.10(0.29)$ & $15.77(7.37)$ & $8.40(0.36)$ \\
\hline$\delta^{15} \mathrm{~N}$ & $-1.51(0.20)$ & $-0.46(0.25)$ & $0.45(0.39)$ & $-2.68(0.70)$ & $-2.54(0.90)$ \\
\hline$\delta^{13} \mathrm{C}$ & $-16.67(0.21)$ & $-17.84(0.63)$ & $-17.81(0.72)$ & $-17.47(0.13)$ & $17.49(0.70)$ \\
\hline Growth $\left(\%\right.$ increase $\left.\mathrm{d}^{-1}\right)$ & $6.86(0.96)$ & $9.54(1.14)$ & $6.40(0.66)$ & $10.36(1.50)$ & $24.66(2.84)$ \\
\hline Chl a $\left(\mathrm{mg} \mathrm{g}^{-1} \mathrm{FW}\right)$ & $42.76(9.70)$ & $49.038(5.82)$ & $112.18(11.88)$ & $227.87(27.18)$ & $400.02(26.84)$ \\
\hline $\mathrm{Chl} b\left(\mathrm{mg} \mathrm{g}^{-1} \mathrm{FW}\right)$ & 38.29 (8.65) & $44.89(7.71)$ & $102.37(8.76)$ & $231.40(34.54)$ & $363.04(19.31)$ \\
\hline $\mathrm{Chl} a+b\left(\mathrm{mg} \mathrm{g}^{-1} \mathrm{FW}\right)$ & $81.052(18.33)$ & $93.93(13.31)$ & $214.56(20.63)$ & $459.26(61.72)$ & $763.05(42.92)$ \\
\hline Chl $a: b\left(\mathrm{mg} \mathrm{g}^{-1} \mathrm{FW}\right)$ & $1.09(0.05)$ & $1.09(0.03)$ & $1.10(0.03)$ & $0.99(0.03)$ & $1.10(0.05)$ \\
\hline Carotenoids (mg g $\left.{ }^{-1} \mathrm{FW}\right)$ & $17.12(2.85)$ & $22.23(3.29)$ & 39.44 (3.26) & 93.64 (13.73) & $67.23(12.11)$ \\
\hline
\end{tabular}


Table 5. Results of 1-way ANOVA for each of the physiological parameters measured on Cladophora sericea in the laboratory following a $10 \mathrm{~d}$ nutrient enrichment experiment ( $\mathrm{df}$ for all tests $=4$ ). Bold values indicate significance at alpha $=0.05$, ns: no significant results. $\mathrm{O}=$ osmocote, $\mathrm{B}=$ both nitrogen and phosphorus enrichment, $\mathrm{N}=$ nitrogen only, $\mathrm{P}=$ phosphorus only and $\mathrm{C}=$ control

\begin{tabular}{|c|c|c|c|c|}
\hline Parameter & MS & $F$ & $\mathrm{p}$ & Pairwise differences \\
\hline Growth $\left(\%\right.$ increase $\left.\mathrm{d}^{-1}\right)$ & 169.44 & 21.76 & $<0.001$ & $\mathrm{O}>$ all \\
\hline $\mathrm{rETR}_{\max }$ & 22.17 & 2.47 & 0.11 & ns \\
\hline Alpha & 0.0021 & 0.77 & 0.57 & ns \\
\hline$E_{k}$ & 766 & 0.54 & 0.71 & $\mathrm{~ns}$ \\
\hline$F_{\mathrm{v}} / F_{\mathrm{m}}$ & 0.021 & 6.52 & 0.008 & $\mathrm{O}>\mathrm{C}, \mathrm{P}$ and $\mathrm{B}>\mathrm{C}$ \\
\hline$\% \mathrm{C}^{\mathrm{MI}}$ & 6.56 & 14.70 & $<0.001$ & $\mathrm{~B}<$ all \\
\hline$\% \mathrm{~N}$ & 4.19 & 5.13 & 0.016 & $\mathrm{~B}<\mathrm{O}, \mathrm{C}$ \\
\hline$\% \mathrm{P}$ & 0.0004 & 3.85 & 0.038 & B > all \\
\hline$C: N$ & 133.9 & 3.25 & 0.059 & ns \\
\hline $\mathrm{N}: \mathrm{P}$ & 1115 & 6.87 & 0.006 & $\mathrm{~N}>\mathrm{C}, \mathrm{O}$ \\
\hline$\delta^{15} \mathrm{~N}$ & 5.43 & 5.82 & 0.011 & $\mathrm{O}, \mathrm{B}>\mathrm{N}$ \\
\hline$\delta^{13} \mathrm{C}$ & 0.67 & 0.77 & 0.57 & $\mathrm{~ns}$ \\
\hline Chl a & 67766 & 65.36 & $<0.001$ & $\mathrm{O}>$ all, $\mathrm{B}>\mathrm{C}, \mathrm{N}, \mathrm{P}$ \\
\hline Chl $b$ & 58220 & 54.60 & $<0.001$ & $\mathrm{O}>$ all, $\mathrm{B}>\mathrm{C}, \mathrm{N}, \mathrm{P}$ \\
\hline Carotenoids & 12002 & 54.88 & $<0.001$ & $\mathrm{O}>$ all, $\mathrm{B}>\mathrm{C}, \mathrm{N}, \mathrm{P}$ \\
\hline
\end{tabular}

and/or perhaps using a different C source than those at shallower sites. Tissue phosphorus did not show any trends with depth, suggesting that phosphorus is not independently contributing to bloom dynamics. The $\mathrm{C}: \mathrm{N}$ ratios indicate that algae growing at the shallow sites were less nutrient limited than samples at any of the other sites. These data generally suggest that the nutrient dynamics of this bloom are complex; it appears that $C$. sericea growing close to shore was using land-based nutrients, but clearly other sources are involved.

The fluorescence data show that while there appears to be a decline in rETR with depth, all values are high and similar to other weedy tropical green algae (Necchi 2003). The lack of a typical sun-shade acclimation pattern (Smith et al. 2004) in Cladophora

Leichter et al. 2003, Smith et al. 2004). $\delta^{13} \mathrm{C}$ was the least negative at the shallow sites, suggesting that metabolic activity of the alga was highest at this site, reducing the enzymatic discrimination between ${ }^{12} \mathrm{C}$ and ${ }^{13} \mathrm{C}$ (MacLeod \& Barton 1998). Algae growing at intermediate depths (between 9 and $25 \mathrm{~m}$ ) had lower $\delta^{13} \mathrm{C}$ values than samples growing at either 3 or $34 \mathrm{~m}$. Interestingly, $\delta^{13} \mathrm{C}$ at $34 \mathrm{~m}$ was also high, suggesting that $\mathrm{C}$ was limiting or that algae were growing faster

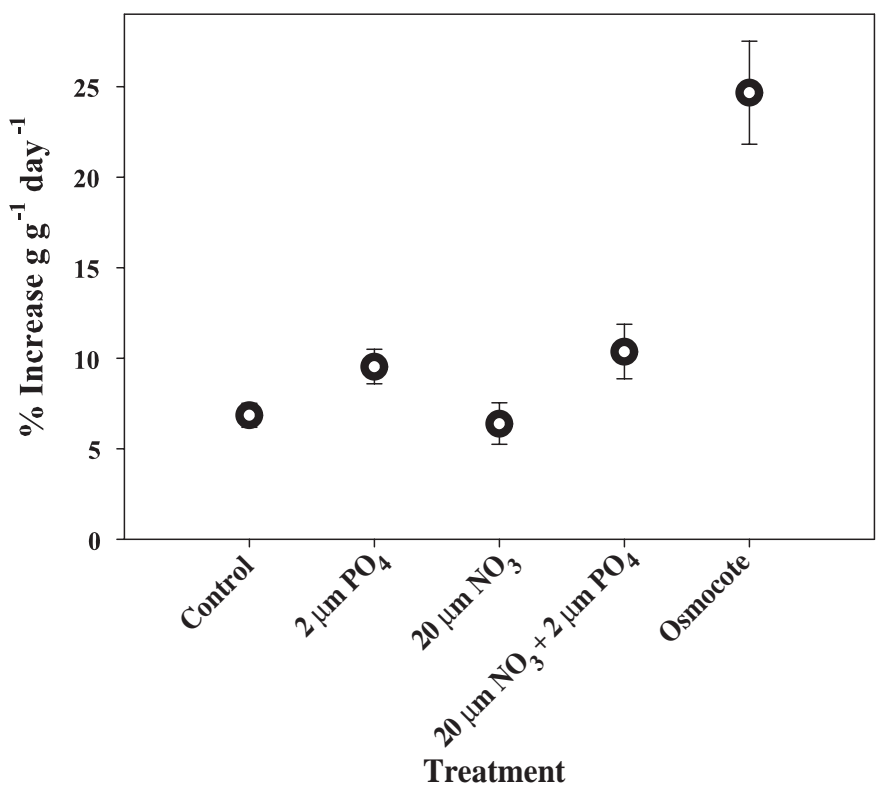

Fig. 9. Cladophora sericea. Growth rates from laboratory nutrient enrichment experiment. Units are percent increase in wet wt $\mathrm{d}^{-1}$; values are means $\pm 1 \mathrm{SE}, \mathrm{n}=3$ sericea across the depth range (irradiance values ranged from 40 to 300 PAR) sampled suggests that the lower depth limit of this alga is much beyond $34 \mathrm{~m}$. High ETR across a broad range of irradiances may be an important characteristic of bloom-forming algae. The patterns observed here are intriguing and warrant further investigation.

\section{Laboratory experimentation}

Growth and a number of physiological parameters of Cladophora sericea showed the largest overall increase in response to a commercial fertilizer. These results suggest that the presence of both nitrate and ammonium may have enhanced algal growth or that the slow-release nature of Osmocote may have provided a more consistent nutrient source to the algae in this experiment. $\delta^{15} \mathrm{~N}$ of algal tissue following completion of this experiment yielded values between 0 and $-4 \%$ (data not shown), much lower than those observed in the field, reflecting the atmospheric origin of the inorganic nitrogen used in fertilizer synthesis. Nevertheless, the large increase in growth in response to nutrient enrichment suggests that this species is capable of rapid population explosion.

\section{General comments}

The reefs of Bermuda have experienced large-scale blooms of the alga Cladophora prolifera since 1966 in shallow protected embayments to a depth of $10 \mathrm{~m}$. Re- 

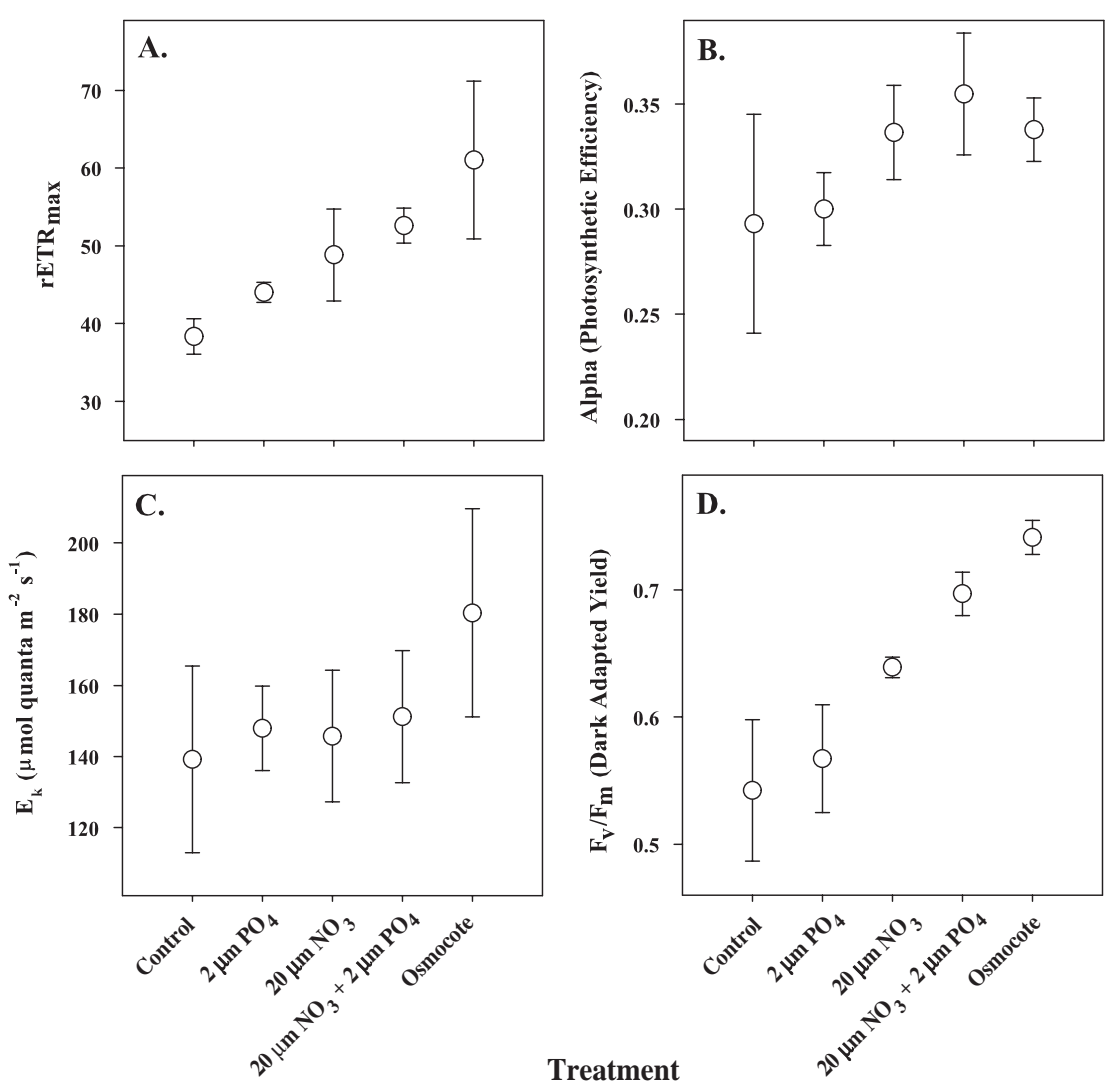

Fig. 10. Fluorescence parameters for Cladophora sericea following $10 \mathrm{~d}$ nutrient enrichment experiment in the laboratory; values are means $\pm 1 \mathrm{SE}, \mathrm{n}=3$

Recently, Umezawa et al. (2002b) examined the feasibility of using nutrient concentrations and stable isotope values from algal tissue as markers for terrestrial nutrient use by marine plants. Significant relationships were found between $\delta^{15} \mathrm{~N}$ in algal tissue and distance from shore. The slopes of these regression relationships varied from site to site depending on residence time of the seawater and fluxes of terrestrial nitrogen. Tissue C:N values for Dictyota and Padina species with simple blade morphologies were quite variable and generally did not show distinct gradients with distance from shore. In some cases, however, significant correlations were found between tissue $\mathrm{C}: \mathrm{N}$ and values of water column nitrogen, but in other cases this did not occur. The observed variation is likely the result of differences in morphology, growth rates, physiology, and cellular storage capacity among these species (Fong et al. 2001, Umezawa et al. 2002b). Nevertheless, tissue $\delta^{15} \mathrm{~N}$ values were similar for different algae growing in the same location, suggesting that this technique can be a useful indicator of the

search conducted on the bloom in the 1970s and 1980s demonstrated that the alga was nutrient limited (Bach \& Josselyn 1978, 1979, Lapointe \& O'Connell 1989) and various nutrient enrichment treatments led to increased growth and productivity. Bach \& Josselyn (1979) demonstrated that light limitation occurred around $10 \mathrm{~m}$, thus explaining algal depth distribution. Schramm \& Booth (1981) suggested that excessive growth of C. prolifera was not the result of nutrient enrichment per se but was due to its competitive advantages, namely the ability to tolerate $\mathrm{H}_{2} \mathrm{~S}$ and anaerobic conditions. Many other studies indicate that the blooms result from enhanced growth due to nutrient-enriched groundwater; it has also been suggested that the alga may be a cryptic non-indigenous species (Bach \& Josselyn 1978, 1979, Lapointe \& O'Connell 1989). In general, these studies lack more direct links between groundwater and algal abundance such as stable isotope analysis or other indicator nutrients such as silicate and/or salinity levels. Lapointe \& O'Connell (1989) measured sediment porewater nutrient concentrations and found significantly elevated concentrations in comparison to back groundwater column levels but did not link these observations with changes in algal parameters. source of nutrient input assuming that a range of $\delta^{15} \mathrm{~N}$ values exists between oceanic, coastal, and terrestrial sources (Umezawa et al. 2002b).

$\delta^{15} \mathrm{~N}$ values in macroalgal tissue have also been used as a proxy for estimating the zone of influence for sewage plumes in coastal and estuarine systems (Costanzo et al. 2001, Cole et al. 2004, Savage \& Elmgren 2004). By sampling algal tissue at various distances from a specific source (sewage outfall, treatment facility, spill, etc.) one can map the influence of sewage-derived nitrogen in the nearshore environment. Algae often have distinctive $\delta^{15} \mathrm{~N}$ signatures that reflect the source of their inorganic nitrogen. For example, Cole et al. (2004) found that macrophytes grown in sewage-derived nitrogen have $\delta^{15} \mathrm{~N}$ signatures generally between 7 and $14 \%$. However, because stable isotopes represent an integrated history of sources, pathways, and processes, the use of $\delta^{15} \mathrm{~N}$ in macroalgae as an indicator of sewage pollution is more difficult in areas that have complex land-use patterns. In our study, nitrogen input via anthropogenic sources can be the result of several different sources including sewage (both from injection wells and septic tanks) and agricultural, golf course, and landscaping fertiliz- 
ers. Nevertheless, we did find significant enrichment in $\delta^{15} \mathrm{~N}$ from algal samples collected close to shore, suggesting that these algae were utilizing at least some land-based nitrogen. In the future it would be useful to analyze $\delta^{15} \mathrm{~N}$ in porewater and various freshwater sources (springs, wells, etc.) and to grow algae in these different sources (sewage, fertilizer, etc.) to determine precise signatures of $\delta^{15} \mathrm{~N}$ in algal tissue in relation to particular nitrogen sources.

Despite some of the similarities between Cladophora blooms in Bermuda and those of West Maui, Bermuda's blooms persist and are restricted to relatively shallow protected nearshore environments. On Maui, blooms are ephemeral, exist on open exposed shorelines, and can be found from shore to over $34 \mathrm{~m}$ depth. While our data suggest that $C$. sericea may be using terrestrial nutrient sources, other, as yet unexplored, factors are also likely to be involved with bloom formation and senescence. A number of physical variables such as temperature, upwelling, irradiance, rainfall, current speed, and direction may all independently or synergistically interact to produce the conditions necessary for rapid growth of C. sericea. Other factors that may influence bloom cycles include undescribed traits of life history. Physical environmental factors and biological factors, and their interaction, emerge as likely drivers for bloom cycles.

Most algal blooms on coral reefs either result in, or are associated with, phase shifts where reef-building corals are replaced by fleshy macroalgae. Reports of ephemeral algal blooms on coral reefs are much less common. Because of the general lack of information about these phenomena from the tropics, absolute causes and consequences remain unclear. Because of the similarities between the Cladophora sericea bloom on Maui's reefs and other ephemeral green macroalgal blooms from temperate marine and freshwater systems it seems likely that similar physical and biological factors are involved.

A robust monitoring program is needed on Maui's reefs to adequately characterize the nutrient environment and the benthos both spatially and temporally. Results from the Hawai'i Coral Reef Assessment and Monitoring Program (CRAMP) at KBP on Maui have shown that coral cover has significantly decreased at both 3 and $7 \mathrm{~m}$ depths (11.1 and $8.3 \%$ decrease, respectively) over the last several years (Jokiel et al. 2004). Whether or not the decrease in coral cover is directly or indirectly linked to Cladophora blooms remains unknown. Nevertheless, the scale and magnitude (both ecologically and economically) of such bloom events are profound, and more research is needed to understand the bloom dynamics of this alga, its interaction with other reef species, and the ultimate consequences of such blooms to ecosystem structure and function as a whole.
Acknowledgements. We thank L. McCook, C. Birkeland and 2 anonymous reviewers for providing valuable comments that helped to improve the manuscript. S. Hau, Department of Land and Natural Resources, provided invaluable boat and technical support in the field. C. L. Hunter provided valuable intellectual comments. L. Preskitt, P. Vroom, E. Brown, and R. Okano helped with fieldwork. F. Sansone helped with the development of porewater sampling devices. This research was funded in part by the University of Hawai'i Sea Grant program NA86RG0041 and the National Oceanic and Atmospheric Administration, Coastal Ocean Program, under awards NA160A1449 and NA160A2412 to the University of Hawai'i for the Hawai'i Coral Reef Initiative Research Program.

\section{LITERATURE CITED}

Bach SD, Josselyn MN (1978) Mass blooms of the alga Cladophora in Bermuda. Mar Pollut Bull 9:34-37

Bach SD, Josselyn MN (1979) Production and biomass of Cladophora prolifera in Bermuda. Bot Mar 22:163-168

Banner AH (1974) Kane'ohe Bay Hawai'i: urban pollution and a coral reef ecosystem. Proc 2nd Int Coral Reef Symp 2: 685-702

Belliveau SA, Paul VJ (2002) Effects of herbivory and nutrients on the early colonization of crustose coralline algae and fleshy algae. Mar Ecol Prog Ser 232:105-114

Bellwood DR, Hughes TP, Folke C, Nystrom M (2004) Confronting the coral reef crisis. Nature 429(6994):827-833

Birch PB, Gordon DM, McComb AJ (1981) Nitrogen and phosphorus nutrition of Cladophora in the Peel-Harvey Estuarine System, Western Australia. Bot Mar 24:381-387

Carpenter RC (1990) Mass mortality of Diadema antillarum. Mar Biol 104:67-77

Cole ML, Valiela I, Kroeger KD, Fry B and 6 others (2004) Assessment of a $\delta^{15} \mathrm{~N}$ isotopic method to indicate anthropogenic eutrophication in aquatic ecosystems. J Environ Qual 33:124-132

Costanzo SD, O'Donohue MJ, Dennison WC (2001) A new approach for detecting and mapping sewage impacts. Mar Pollut Bull 42:149-156

Diaz-Pulido G, McCook LJ (2003) Relative roles of herbivory and nutrients in the recruitment of coral-reef seaweeds Ecology 84:2026-2033

Dodds WK, Gudder DA (1992) The ecology of Cladophora. J Phycol 28:415-427

Done TJ (1992) Phase-shifts in coral reef communities and their ecological significance. Hydrobiologia 247:121-132

Duarte CM (1995) Submerged aquatic vegetation in relation to nutrient regimes. Ophelia 41:87-112

Ensminger I, Hagen C, Braune W (2000) Strategies providing success in a variable habitat. I. Relationships of environmental factors and dominance of Cladophora glomerata. Plant Cell Environ 23:1119-1128

Falter JL, Sansone FJ (2000) Shallow pore water sampling in reef sediments. Coral Reefs 19:93-97

Fong P, Kamer K, Boyer KE (2001) Nutrient content of macroalgae with differing morphologies may indicate sources of nutrients for tropical marine systems. Mar Ecol Prog Ser 220:137-152

Hatcher BG, Larkum AWD (1983) An experimental analysis of the factors controlling the standing crop of the epilithic algal community on a coral reef. J Exp Mar Biol Ecol 69: 61-84

Hughes T (1994) Catastrophes, phase-shifts and large-scale degradation of a Caribbean coral reef. Science 265: $1547-1551$ 
Hughes T, Connell JH (1999) Multiple stressors on coral reefs: a long-term prospective. Limnol Oceanogr 44:932-940

Hughes T, Szmant AM, Steneck R, Carpenter R, Miller S (1999) Algal blooms on coral reefs: What are the causes? Limnol Oceanogr 44:1583-1586

Hunter CL, Evans CW (1995) Coral reefs in Kane'ohe Bay, Hawai'i: two centuries of western influence and two decades of data. Bull Mar Sci 57:501-515

Jokiel PL, Brown E, Friedlander A, Rodgers S, Smith W (2004) Hawai'i coral reef monitoring and assessment program: spatial patterns and temporal dynamics in reef coral communities. Pac Sci 58:159-174

Jompa J, McCook LJ (2003a) Effects of competition and herbivory on interactions between a hard coral and a brown alga. J Exp Mar Biol Ecol 271:25-39

Jompa J, McCook LJ (2003b) The effects of nutrients and herbivory on competition between a hard coral (Porites cylindrica) and a brown alga (Lobophora variegata). Limnol Oceanogr 47:527-534

Knowlton N (2001) The future of coral reefs. Proc Natl Acad Sci 98:5419-5425

Lapointe BE (1997) Nutrient thresholds for bottom-up control of macroalgal blooms in Jamaica and southeast Florida Limnol Oceanogr 42:1119-1131

Lapointe BE (1999) Simultaneous top-down and bottom-up forces control macroalgal blooms on coral reefs. Limnol Oceanogr 44:1586-1592

Lapointe BE, O'Connell J (1989) Nutrient-enhanced growth of Cladophora prolifera in Harrington Sound, Bermuda: eutrophication of a confined, phosphorus-limited marine ecosystem. Estuar Coast Shelf Sci 28:347-360

Larned ST (1998) Nitrogen versus phosphorus limited growth and sources of nutrients for coral reef macroalgae. Mar Biol 132:409-421

Leichter JJ, Stewart HL, Miller SL (2003) Episodic nutrient transport to Florida coral reefs. Limnol Oceanogr 48:1394-1407

Lirman D (2001) Competition between macroalgae and corals: effects of herbivore exclusion and increased algal biomass on coral survivorship and growth. Coral Reefs 19:392-399

Lotze HK, Schramm W (2000) Ecophysiological traits explain species dominance patterns in macroalgal blooms. J Phycol 36:287-295

MacLeod NA, Barton DR (1998) Effects of light intensity, water velocity and species composition on carbon and nitrogen stable isotopes in periphyton. Can J Fish Aquat Sci 55:1919-1925

Maragos JE, Evans C, Holthus P (1985) Reef corals in Kane'ohe Bay six years before and after termination of sewage discharges. Proc 5th Int Coral Reef Symp 4: 189-195

McClanahan TR, Cokos BA, Sala E (2002) Algal growth and species composition under experimental control of herbivory, phosphorus and coral abundance in Glovers Reef, Belize. Mar Pollut Bull 44:441-451

McCook LJ (1997) Effects of herbivory on zonation of Sargassum spp. within fringing reefs of the central Great Barrier Reef. Mar Biol 129:713-722

McCook LJ (1999) Macroalgae, nutrients and phase-shift on coral reefs: scientific issues and management consequences for the Great Barrier Reef. Coral Reefs 18: $357-367$

McCook LJ (2001) Competition between corals and algal turfs along a gradient of terrestrial influence in the nearshore central Great Barrier Reef. Coral Reefs 19:419-425

McCook LJ, Jompa J, Diaz-Pulido G (2001) Competition between corals and algae on coral reefs: a review of evidence and mechanisms. Coral Reefs 19:400-417

Miller MW, Hay ME, Miller SL, Malone D, Sotka EE, Szmant AM (1999) Effects of nutrients versus herbivores on reef algae: a new method for manipulating nutrients on coral reefs. Limnol Oceanogr 44:1847-1861

Moran R, Porath D (1980) Chlorophyll determination in intact tissues using N,N-dimethylformamine. Plant Physiol 65:478-479

Morand P, Briand X (1996) Excessive growth of macroalgae: a symptom of environmental disturbance. Bot Mar 39: 491-516

Necchi O (2003) Photosynthetic responses to temperature in tropical lotic macroalgae. Phycol Res 52:140-148

Paalme T, Kukk H, Kotta J, Orav H (2002) In vitro and in situ decomposition of nuisance macroalgae Cladophora glomerata and Pilayella littoralis. Hydrobiologia 475/476: 469-476

Peckol P, DeMeo-Anderson B, Rivers J, Valiela I, Maldonado M, Yates J (1994) Growth, nutrient uptake capacities and tissue constituents of the macroalgae Cladophora vagabunda and Gracilaria tikvahiae related to sitespecific nitrogen loading rates. Mar Biol 121:175-185

Platt T, Gallegos CL, Harrison WG (1980) Photoinhibition of photosynthesis in natural marine assemblages of marine phytoplankton. J Mar Res 38:687-701

Porter JW, Lewis SK, Porter KG (1999) The effect of multiple stressors on the Florida Keys coral reef ecosystem: a landscape hypothesis and a physiological test. Limnol Oceanogr 44:941-949

Raffaelli DG, Raven JA, Poole LJ (1998) Ecological impact of green macroalgal blooms. Oceanogr Mar Biol Annu Rev 36:97-125

Ralph PJ, Gademann R, Dennison WC (1998) In situ seagrass photosynthesis measured using a submersible, pulseamplitude modulated fluorometer. Mar Biol 132:367-373

Ravera O (2000) The lagoon of Venice: the result of both natural factors and human influence. J Limnol 59:19-30

Runca E, Bernstein A, Postma L, DiSilvio G (1996) Control of macroalgae blooms in the Lagoon of Venice. Ocean Coast Manage 30:235-257

Savage C, Elmgren R (2004) Macroalgal (Fucus vesiculosus) delta $\mathrm{N}-15$ values trace decrease in sewage influence. Ecol Appl 14:517-526

Schramm W, Booth W (1981) Mass bloom of the alga Cladophora prolifera in Bermuda: productivity and phosphorous accumulation. Bot Mar 24:419-426

Schreiber U, Gademann R, Ralph PJ (1997) Assessment of photosynthetic performance of Prochloron in Lissoclinum patella in hospite by chlorophyll fluorescence measurements. Plant Cell Physiol 38:945-951

Smith JE, Smith CM, Hunter CL (2001) An experimental analysis of the effects of herbivory and nutrient enrichment on benthic community dynamics on a Hawaiian reef. Coral Reefs 19:332-342

Smith JE, Hunter CL, Smith CM (2002) Distribution and reproductive characteristics of nonindigenous and invasive marine algae in the Hawaiian Islands. Pac Sci 56: 299-315

Smith JE, Smith C, Vroom P, Beach K, Miller S (2004) Nutrient dynamics of the green alga Halimeda tuna on Conch Reef, Florida Keys: possible influence of internal tides on nutrient status and physiology. Limnol Oceanogr 49:1923-1936

Smith SV, Kimmerer WJ, Laws EA, Brock RE, Walsh TW (1981) Kane'ohe sewage diversion experiment: perspectives on ecosystem response to nutritional perturbation. Pac Sci 35:279-395 
Stiger V, Payri CE (1999a) Spatial and temporal patterns of settlement of the brown macroalgae Turbinaria ornata and Sargassum mangarevense in a coral reef on Tahiti. Mar Ecol Prog Ser 191:91-100

Stiger V, Payri CE (1999b) Spatial and seasonal variations in the biological characteristics of two invasive brown algae, Turbinaria ornata (Turner) J-Agardh and Sargassum mangarevense (Grunow) Setchell (Satgassaceae, Fucales) spreading on the reefs of Tahiti. Bot Mar 42: 295-306

Stimson J, Larned ST, Conklin E (2001) Effects of herbivory, nutrient levels, and introduced algae on the distribution and abundance of the invasive macroalga Dictyosphaeria cavernosa in Kane'ohe Bay, Hawai'i. Coral Reefs 19:343-357

Taylor R, Fletcher RL, Raven JA (2001) Preliminary studies on the growth of selected 'green tide' algae in laboratory culture: effects of irradiance, temperature, salinity and nutrients on growth rate. Bot Mar 44:327-336

Thacker RW, Ginsburg DW, Paul VJ (2001) Effects of herbivore exclusion and nutrient enrichment on coral reef macroalgae and cyanobacteria. Coral Reefs 19:318-329

Thybo-Christesen M, Rasmussen MB, Blackburn TH (1993) Nutrient fluxes and growth of Cladophora sericea in a shallow Danish bay. Mar Ecol Prog Ser 100:273-281

Editorial responsibility: Charles Birkeland (Contributing Editor), Honolulu, Hawaii, USA
Tribble GW, Sansone FJ, Yuan-Hui L (1992) Hydraulic exchange between a coral reef and surface sea water Geol Soc Am Bul 104:1280-1291

Umezawa Y, Miyajima T, Kayanne H (2002a) Significance of groundwater nitrogen discharge into coral reefs at Ishigaki Island, southwest of Japan. Coral Reefs 21: 346-356

Umezawa Y, Miyajima T, Yamamuro M, Kayanne H, Koike I (2002b) Fine-scale mapping of land-derived nitrogen in coral reefs by $\delta^{15} \mathrm{~N}$ in macroalgae. Limnol Oceanogr 47: 1405-1416

Valiela I, McClelland J, Hauxwell J, Behr PJ, Hersh D, Foreman K (1997) Macroalgal blooms in shallow estuaries: controls and ecophysiological and ecosystem consequences. Limnol Oceanogr 42:1105-1118

Van Kooten O, Snell JFH (1990) The use of chlorophyll fluorescence nomenclature in plant stress physiology. Plant Physiol 25:147-150

White AJ, Critchley C (1999) Rapid light curves: a new fluorescence method to assess the state of the photosynthetic apparatus. Photosynth Res 59:63-72

Williams ID, Polunin NVC (2001) Large-scale associations between macroalgal cover and grazer biomass on middepth reefs in the Caribbean. Coral Reefs 19:358-366

Submitted: July 17, 2004; Accepted: May 3, 2005

Proofs received from author(s): October 18, 2005 